\title{
Assessment of Polycyclic Aromatic Hydrocarbons (PAHs) in Sediment and Fish Samples of River Owan, and Agricultural Soil Around The Same River in EDO State, Nigeria
}

\author{
Akinyinka Akinnusotu ${ }^{1,2, *}$, Justinah E. Ukpebor ${ }^{2}$, Felix E. Okiemen ${ }^{2}$ \\ 1 Department of Science Laboratory Technology, Rufus Giwa Polytechnic, Owo, Nigeria; e-mail@e-mail.com \\ 2 University of Benin, Department of Chemistry, Benin City, Nigeria \\ * Correspondence: akinnusotuakinyinka@gmail.com; Tel.: ++2348032209692
}

\begin{abstract}
Polycyclic aromatic hydrocarbons (PAHs) belong to the group of persistent organic pollutants (POPs) which are major environmental pollutants associated with the environment. In this study (preliminary), the concentrations of eighteen (18) PAHs in soil, sediment and fish sample (Clarias anguillaris) of Owan River and agricultural soil samples around the river in Edo State were studied using standard analytical methods. Gas chromatograph equipped with flame ionization detector (GC-FID) was used for the determination of PAHs. The study revealed the presence of the 18 determined PAHs in the soil, sediment and fish (Clarias anguillaris) samples in varying concentrations. The concentrations of PAHs in the soil samples ranged between 0.0000-0.0463 $(\mu \mathrm{g} / \mathrm{kg})$ with total concentrations of $\sum 0.2390(\mu \mathrm{g} / \mathrm{kg})$ for soil sample 1 and $0.0000-0.0506(\mu \mathrm{g} / \mathrm{kg})$ with total concentration of $\sum 0.2700(\mu \mathrm{g} / \mathrm{kg})$ for soil sample from location 2 . The concentrations of the PAHs components in the sediments samples ranged between $0.00332-0.0319(\mu \mathrm{g} / \mathrm{kg})$ with total concentration of $\sum 0.150592(\mu \mathrm{g} / \mathrm{kg})$ for the sediment sample $1 ; 0.002092-0.05866(\mu \mathrm{g} / \mathrm{kg})$ with total concentration of $\sum 0.0312183(\mu \mathrm{g} / \mathrm{kg})$ for the sediment sample 2. The concentration of PAHs components in the fish sample ranged between $0.0000-0.0746(\mu \mathrm{g} / \mathrm{kg})$ with total concentration of $\sum 0.300(\mu \mathrm{g} / \mathrm{kg})$. The concentrations of PAHs were higher in the soil samples than in the sediment samples. Concentrations of the PAHs residues detected in the fish samples were higher than that in the soil and sediment samples. In furtherance of this study, the number of sampling stations shall be increase to cover other communities while data generated will be subjected to more ecological risk assessments.
\end{abstract}

Keywords: persistent pollutants; PAHs; river owan; ecology; sediment

\section{Introduction}

Polycyclic aromatic hydrocarbons (PAHs) are persistent organic pollutants (POPs) that are toxic, distributed and have a potential for bioaccumulation. PAHs consist of at least two fused benzene rings in different arrangements having only carbon and hydrogen atoms. There are several hundreds of PAHs, only sixteen (16) PAHs are listed by the US Environmental Protection Agency and European commission as priority pollutants (Zheng et al., 2020; Li et al., 2015; Cui et al., 2016; Banger et al., 2010; Gan et al., 2009). Most of them are formed by a process of: thermal decomposition (pyrolysis) and subsequent recombination (pyrosynthesis) of organic molecules e.g. acenaphthene, acenaphthylene, anthracene, benz(a)anthracene and others (Lawal, 2017; Li et al., 2015; Banger et al., 2010).

PAHs are not easily degradable by microorganisms as a result of their stable aromatic ring structure. Hence, some of them are carcinogenic and mutagenic in nature. They are easily diffused and transported over along range distances (Gao et al., 2018; Lawal, 2017; Kuppusamy et al., 2016; Yu et al., 2015). They enter into the environment through various routes, including domestic and industrial effluents discharges, oil spillage, asphalt particles, atmospheric transport, vehicles exhaust 
and so on. Soil and river sediments are the primary reservoir and sinks for PAHs in the terrestrial environment, because they are readily absorbed by organic matter (Hussein et al., 2016; Lang et al., 2015; Botkin and Keller 2014; Feng et al., 2009; Srogi, 2007; Wang et al., 2013). Their accumulation in agricultural soil, sediment and biota may lead to contamination of food chains, which could cause a potential risk to human health due to their potential to bio-accumulate and persist in the environment. PAHs have been of scientific interest for many years (Laigi et al., 2020; Gao et al., 2018; Lawal, 2017; Mahmoud and Abbas 2016; Li et al., 2015; Orecchio and Papuzza 2009).

As a persistent organic pollutants (POPs), much research has focused on characterizing their concentrations and health effects during the past decade using various environmental risk assessments (Laigi et al., 2020; Gao et al., 2018; Li et al., 2015; Wang et al., 2013; Yu et al., 2015; Lau et al., 2010). Various samples analysed varied from water, soil, sediment and fish samples from various regions ranging from riverine areas, polluted soil, oil spillage sites, industrial sites, agricultural sites and so on (Zheng et al., 2020; Gao et al., 2018; Jiao et al., 2015; Sun et al., 2015; Li et al., 2015; Asagbra et al., 2015; Sun et al., 2015; Yu et al., 2015; Wang et al., 2013; Li et al., 2011; Lau et al., 2010; Ogunfowokan et al., 2003). Developed and developing countries have being paying much attention as a result of the adverse effects they pose to the ecosystem, animals and human health. Major data gaps exist as far as its sources and concentrations in developing countries are concerned (Zheng et al., 2020; Gao et al., 2018; Okedeyi et al., 2013; Jiao et al., 2015; Upadhi and Wokoma, 2012; Nieuwoudt et al., 2011; Ogunfowokan et al., 2003). Hence, the need for this preliminary study to determine the concentrations of PAHs in soil, sediment and fish samples from river Owan in Edo State, Nigeria since there has not been any report of PAHs from this study site and its environs.

\section{Materials and Methods}

\subsection{The Study Area}

River Owan is one of the rivers in Edo State, Nigeria and lies within latitudes 5o $30^{\prime} \mathrm{N}, 6^{\circ} 30^{\prime} \mathrm{N}$ and longitudes $7^{\circ} 30^{\prime} \mathrm{E}, 7^{\circ} 30^{\prime} \mathrm{E}$ respectively. The climate in this area is tropical with two main seasons: wet (April - October) and dry (November - March) seasons.

The river serves the communities around it for various activities: fishing, washing, transportation, cooking, bathing, swimming and drinking. Various domestic wastes are usually dumped into the river by the residents of these communities. The river runs through Okpokhumi, Sabongidda and empties into the River Ose. This region is notable for its intensive agricultural activities (cash and food crops), construction and washing zones of automobiles (repairs and maintenance of canoe and speed boats engines) are other anthropogenic activities along the river banks (Oyakhilome et al., 2019).

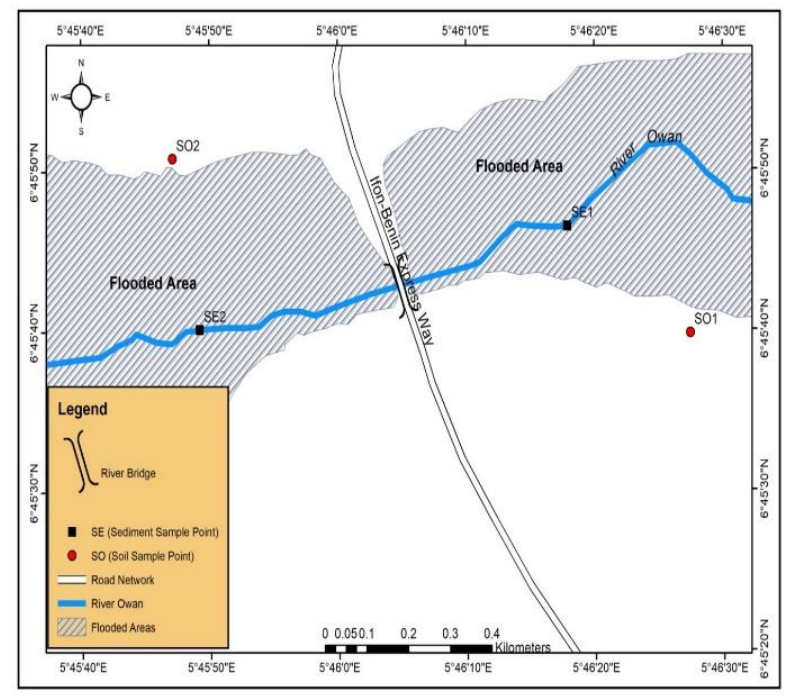

Figure 1. Map of the study area and sampling points. 


\subsection{Sampling and sampling stations}

\subsubsection{Soil}

Two soil samples were collected from agricultural farm sites around the river using two sampling stations. These stations were established based on ecological settings, vegetation and human activities in the area. Stainless steel soil auger was used for the collection at a depth of $0-30 \mathrm{~cm}$. Sampling stations were geo-referenced using Garmin's GPSMAP 76S. The two soil samples were coded SO1 (downstream soil sample) and SO2 (upstream soil sample). Soils samples were placed in cleaned 1 litre glass jars with Teflon lined screw cap, stored in an ice-chest at $4^{\circ} \mathrm{C}$ and transported to the laboratory.

\subsubsection{Sediment}

Two sediment samples were collected at two sampling stations with the aid of a grab sampler in a 1 litre clean glass jar with screw cap, stored in an ice-chest at $4^{\circ} \mathrm{C}$ and transported to the laboratory. The two sediment samples were coded SE1 (downstream sediment sample) and SE2 (upstream sediment sample).

\subsubsection{Fish}

Clarias anguillaris (cat fish) sample was collected from the river using a hook trap, kept in a labeled glass jar, stored in a chest cooler at $4^{\circ} \mathrm{C}$ and transported to the laboratory. The fish sample was identified by an aqua culturist at the Department of Fishery and Aquaculture, Rufus Giwa Polytechnic, Owo, Ondo State, Nigeria. Clarias anguillaris is mainly a bottom feeder and depend largely on detritus (Ugwumba and Ugwumba 2007), and can therefore take up pollutants (Lasheen et al., 2012; Adeyemi et al., 2009).

\subsubsection{Sampling Period}

Sampling was carried out in the month of February, 2019 (during the dry season).

\subsection{Sample treatment and preparation for soil and sediment}

The standard reference method employed in the PAH analysis was US EPA 8240. Soil and sediment samples were air-dried at room temperature in the laboratory, grounded using a porcelain mortar and pestle (previously washed and cleaned with hexane) and sieved using a laboratory $2 \mathrm{~mm}$ sieve.

Ten grams (10g) of sample was carefully weighed into a dried organic free and chromic acid precleaned extraction bottle. Ten grams $(10 \mathrm{~g})$ of anhydrous Sodium Sulphate was added and mixed with a glass rod. Mixture of twenty millilitres $(20 \mathrm{~mL})$ of hexane and dichloromethane in the ratio $3: 1(90 \mathrm{~mL}$ of hexane and $30 \mathrm{~mL}$ of dichloromethane were prepared in a standard flask) was added to the sample. The sample was placed in an organic flask shaker at $500 \mathrm{osc} / \mathrm{min}$ for $30 \mathrm{mins}$

The extract was filtered. The sample was then left in the extraction bottle at laboratory room temperature to concentrate for a minimum of 24 hours until about $2 \mathrm{~mL}$ of concentrated sample was left in the extraction bottle. This was followed by fractionation in activated alumina (neutral) column to separate into aliphatic and aromatic fractions using n-Hexane and Dichloromethane respectively. The aromatic fraction was concentrated to approximately $1.0 \mathrm{~mL}$ using rotary evaporator. The aromatic extract was stored in a dried organic free and chromic acid pre-cleaned glass vials with Teflon rubber caps for analysis. It was refrigerated at $-4^{\circ} \mathrm{C}$ until analysis.

\subsection{Sample Analysis}

Analysis of PAHs was done using Agilent 7890A Gas Chromatography GC equipped with flame ionization detector (Agilent Technologies, California, United States). $1 \mu \mathrm{L}$ of the concentrated sample was injected by means of exmire micro syringe through rubber septum into the column. The gas 
chromatography GC was set at the optimum temperature, $1.00 \mu \mathrm{l}$ of the prepared calibration concentrate extract injected and the GC run as normal. PAH quantification was carried out by CLARITY-GC interfaced software.

Separation occurs as the vapour constituent partition between the gas and liquid phases.

\subsection{Gas Chromatograph Calibration}

The calibration was done with Sigma-Aldrich Chemical (Germany) available PAH Accu Standards. The standard contains the 18 PAHs and was prepared as directed by the manufacturer.

\subsection{Gas Chromatograph analysis Conditions}

The initial oven temperature was $45^{\circ} \mathrm{C}$ which was determined by the ambient temperature of the laboratory. The hold time for the $45^{\circ} \mathrm{C}$ was $2 \mathrm{mins}$. The gradient rate was $15^{\circ} \mathrm{C} / \mathrm{min}$; temperature was allowed to rise to $240^{\circ} \mathrm{C}$ and the injector temperature for samples was $280^{\circ} \mathrm{C}$. After samples have been injected, temperature rise at gradient rate of $10^{\circ} \mathrm{C} / \mathrm{min}$ and end at $300^{\circ} \mathrm{C}$ which is the higher maximum operating temperature indicated on the column box or supplier specification and $8.17 \mathrm{mins}$ was the hold time employed. The detector temperature was $340^{\circ} \mathrm{C}$. Helium was the carrier gas. Other gases: combustion gas- hydrogen and compressed air, coolant- carbon (iv) oxide. Pressure program (set point):14.0psi. Injected volume: $1.00 \mu$.

\subsection{Sample treatment and preparation for the fish sample}

Standard analytical procedure for PAHs as described by US EPA, (1986) was used. The frozen fish sample was homogenized using a warring blender (previously washed and cleaned with hexane) and $100 \mathrm{~mL}$ of acetone was added. Sample was homogenized for 20 minutes at $100 \mathrm{rpm}$ and mixed further with $5 \mathrm{~g}$ of anhydrous sodium sulphate. Extraction was done using a mixture of dichloromethane and $\mathrm{n}$-hexane as solvent in a soxhlet extraction apparatus for about 5 hours. The resulting solvent was eluted with $50 \mathrm{~mL}$-hexane solvent, evaporated again until $1-2 \mathrm{~mL}$.

\subsection{Quality Control}

The GC after start-up was flushed with air to clear the column and prepare for fresh analysis. Samples analysed was accompanied with a quality control (QC) sample and by solvent blank. Standards of $0.1 \mathrm{ppm}$ and $0.5 \mathrm{ppm}$ were chosen for low and high range as quality control standards. Chemicals and reagents were of high grade purity: Acetone $(99.8 \%)$, dichloromethane $(99.5 \%), n-$ hexane (99.8\%) and acetonitrile, cyclohexane, sodium chloride and anhydrous sodium sulphate were of high purity $(99 \%)$.

Statistical analysis

Microsoft Excel package was used for the analysis of data obtained and to generate various charts.

\section{Result and Discussion}

Results of the PAHs are presented using the stacked area charts and detail as appendix 1.

\subsection{Concentration of PAHs in the soil samples}

The concentrations of various PAHs components were presented using the charts (figure 2 and 3). Eighteen (18) PAHs components were examined in the soil samples taken from two sampling stations. The soil samples were coded SO1 (soil sample from sampling location 1) from upstream farm site and $\mathrm{SO} 2$ (soil sample from sampling location 2) from downstream farm site (figure 1). Naphthalene, acenaphthalene and dibenzo(a,h) anthracene were not detected in the soil samples from the two farm locations. 1-MethylNaphthalene was not detected in soil sample from location 2 but was present in soil sample from location 1 at a concentration of $0.0307 \mu \mathrm{g} / \mathrm{kg}$. The concentration 
of 2-MethylNaphthalene were $0.0282 \mu \mathrm{g} / \mathrm{kg}$ and $0.0250 \mu \mathrm{g} / \mathrm{kg}$ for soil sample from location 1 and 2 respectively. The concentration of acenaphthene, fluorene, phenanthrene and anthracene were $0.0065,0.0136,0.0094$ and $0.0048 \mu \mathrm{g} / \mathrm{kg}$ for soil sample from location 1 and $0.0095,0.056,0.0155$ and $0.0123 \mu \mathrm{g} / \mathrm{kg}$ for the same components in soil sample from location 2. The concentration of pyrene, fluoranthrene, benzo(a)anthracene and chrycene were $0.0048,0.0440,0.0027$ and $0.0083 \mu \mathrm{g} / \mathrm{kg}$ for soil sample from location 1 (SO1) while $0.0067,0.0490,0.0041$ and $0.0193 \mu \mathrm{g} / \mathrm{kg}$ for soil sample from location 2 (SO2) respectively. The concentration of benzo(k)fluoranthrene, benzo(b)fluoranthrene, Benzo(a)pyrene, Benzo(g,h,i)perylene and Indeno(1,2,3-cd)pyrene were 0.0003, 0.0014, 0.0102, 0.0463 and $0.0227 \mu \mathrm{g} / \mathrm{kg}$ for soil sample from location 1 and $0.0055,0.0006,0.0084,0.0230$ and $0.0406 \mu \mathrm{g} / \mathrm{kg}$ for soil sample from location 2 respectively. The total sum of the PAHs components were $\sum 0.239$ $\mu \mathrm{g} / \mathrm{kg}$ and $\sum 0.270 \mu \mathrm{g} / \mathrm{kg}$ for soil sample from location 1 and 2 respectively. Muntean et al., 2015 studied PAHs in three locations from Transylvania (Cluj Napoca, Jucu and Seica Mare), the total PAHs concentrations ranged from 4.43 to $11.74 \mu \mathrm{g} / \mathrm{kg}$, the highest recorded values being for fluorene $(9.02 \mu \mathrm{g} / \mathrm{kg})$, benzo (b) fluoranthene $(2.85 \mu \mathrm{g} / \mathrm{kg})$ and benzo (a) anthracene $(2.16 \mu \mathrm{g} / \mathrm{kg})$; the highest soil contamination was from samples originating from Seica Mare $(11.74 \mu \mathrm{g} / \mathrm{kg})$ and from Cluj Napoca. The high concentration levels of PAHs were attributed to historical pollution and car traffic. Kim et al., 2019 carried out a study on the top soils of rice paddies from Gyeonggi-do in Korea to assess the spatial distribution and potential sources of PAHs. The total concentrations of PAHs in the soils ranged between 19.53-672.93, 125.01-3106.27, and 51.94-8106.21 mg/kg respectively. Three-ring PAHs were predominant in the soils from Gyeonggi-do while 3-5 ring compounds were abundant in the agricultural soils from other industrial regions. The presence of PAHs was suggested to have originated from pyrogenic sources. The concentrations of PAHs from these regions were higher than the results obtained from this study.

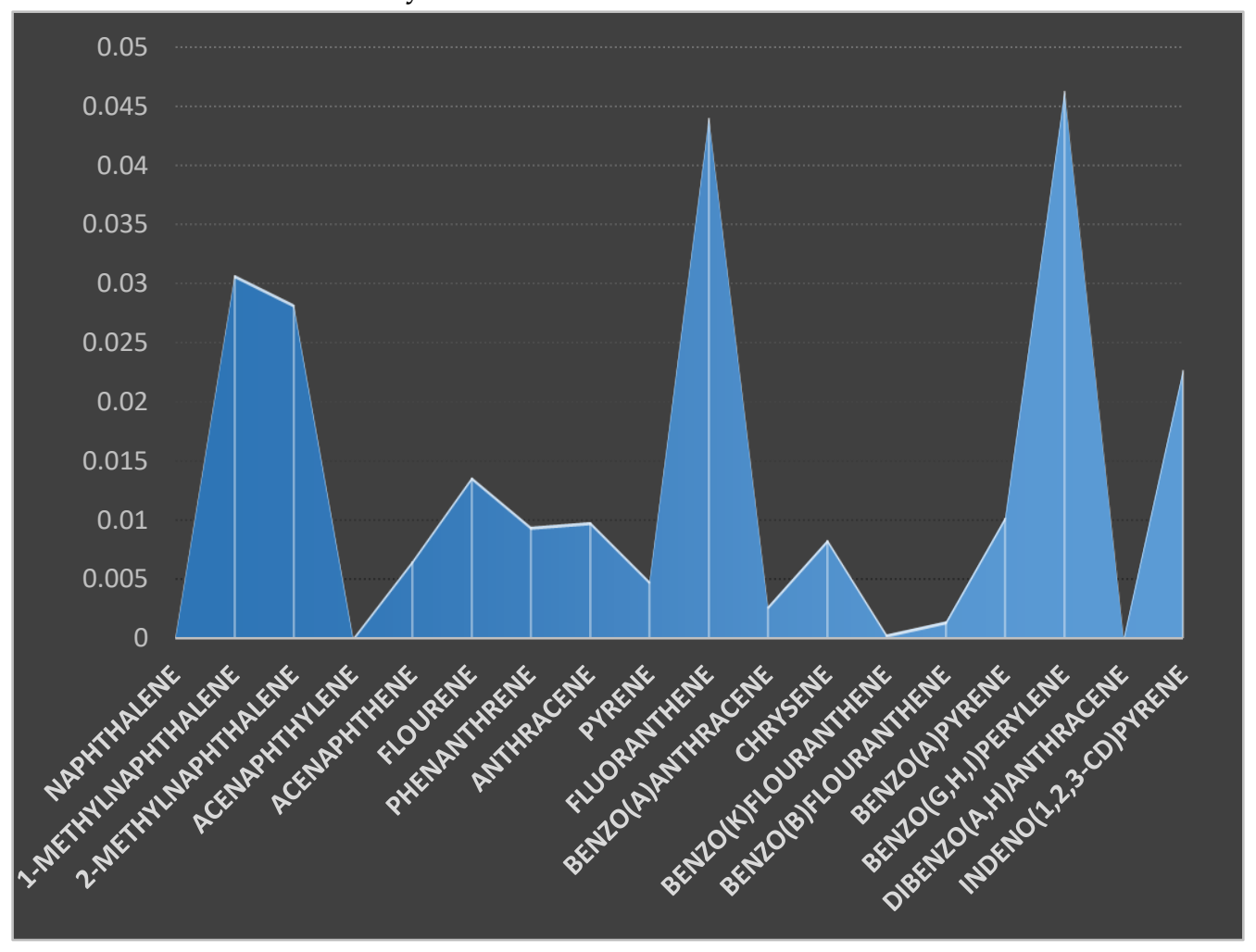

Figure 2. Concentration of PAHs $(\mu \mathrm{g} / \mathrm{kg})$ components in soil sample from location 1. 


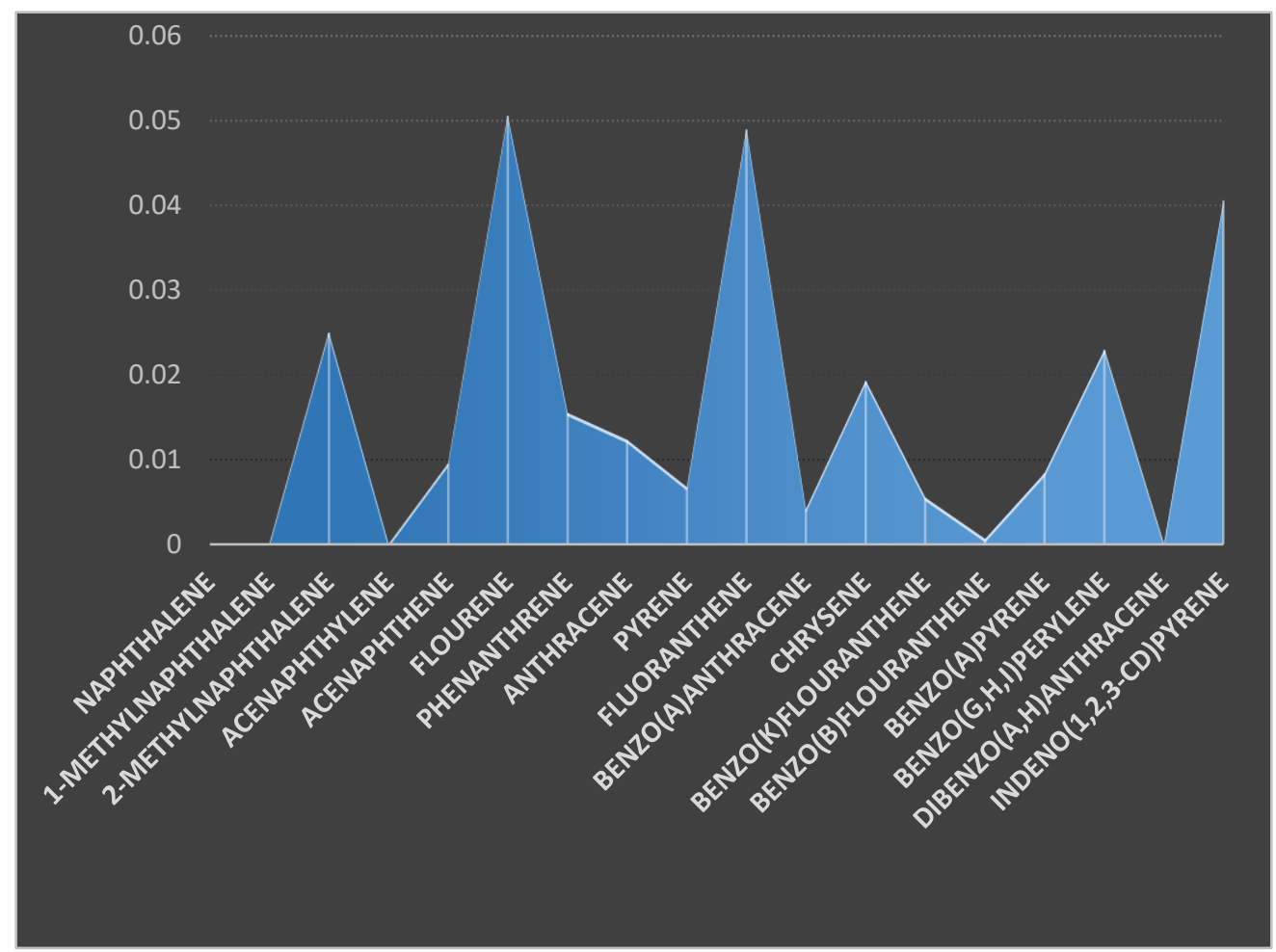

Figure 3. Concentration of PAHs components $(\mu \mathrm{g} / \mathrm{kg})$ in soil sample from location 2.

\subsection{Concentration of PAHs in the sediment samples}

Two sediment samples were taken from two different sampling stations: coded SE1 (upstream) and SE2 (downstream) (figure 1). Eighteen (18) PAHs were determined from the sediment samples and the results presented in the charts (figure 4 and 5). Naphthalene and acenaphthylene were not detected in the sediment samples. Dibenzo(a,h)anthracene and Chrysene were detected in the sediment sample from sampling location 1 with a concentration of 0.0163 and $0.0026 \mu \mathrm{g} / \mathrm{kg}$ but not detected in sediment sample from sampling location 2. The concentrations of 1-MethylNaphthalene, 2-MethylNaphthalene, acenaphthene, fluorene, phenanthrene and anthracene were $0.0101,0.0147$, $0.0033,0.0086,0.0039$ and $0.0070 \mu \mathrm{g} / \mathrm{kg}$ for sediment sample from location 1 and $0.0152,0.0196,0.0087$, $0.0294,0.0069$ and $0.0064 \mu \mathrm{g} / \mathrm{kg}$ for the same components of PAHs in sediment sample from sampling location 2. The concentration of benzo(k)fluoranthene, benzo(b)fluoranthene, benzo(a)pyrene, benzo(g,h,i)perylene and indeno(1,2,3-cd)pyrene were $0.0008,0.0023,0.0075,0.0071$ and $0.0054 \mu \mathrm{g} / \mathrm{kg}$ for sediment sample from location 1 while $0.0036,0.0017,0.0036,0.0084$ and $0.0239 \mu \mathrm{g} / \mathrm{kg}$ respectively for the same PAHs components in location 2. The total summation of PAHs components for sediment sample 1 was $\sum 0.105 \mu \mathrm{g} / \mathrm{kg}$ and $\sum 0.146 \mu \mathrm{g} / \mathrm{kg}$ for location 2 .

A research conducted by Sun et al., 2016 on sediments from a mixed use reservoir from Shitou Koumen to determine PAHs recorded no value for Acy, Bkf, and DahA while the concentrations of Nap, Ace, Flo and Phe ranged between 535.4-1009.6, 0-21.43, 23.63-110.3 and 150.40-637.0ng/g. The total PAHs concentrations in sediments from this reservoir (Shitou Koumen Resevoir) ranged from $1294.51-2755.35 \mathrm{ng} / \mathrm{g}$ with a mean concentration $1757.54 \mathrm{ng} / \mathrm{g}$. The concentration of PAHs reported by Sun et al., 2016 was very high compared to this study, this was attributed to polluted river treatment and potentially polluted tributary. This was also supported by Mirza et al., 2014. Major sources of PAHs in river sediments have being attributed to oil spillage, coal incineration and vehicular emissions as reported by Yang et al., 2014. Agnieska et al., 2017 researched on the concentration of PAHs in bottom sediments collected from reservoir in South-Eastern Poland, reported the total concentration that ranged from $150-33,900 \mathrm{ug} / \mathrm{kg}$. They attributed the origin of PAHs to pyrolytic activities and petrogenic sources. 
A research carried out by Zhao et al., 2017 on PAHs in sediments from river Qinhuai and lake Xuanwu, Nanjing China reported a total concentration of range of PAHs from $796.2 \mathrm{ng} / \mathrm{g}$ to $10,470 \mathrm{ng} / \mathrm{g}$ with an average of $2,713.8 \mathrm{ng} / \mathrm{g}$. The research work suggested that the PAHs in the river Qinhuai were mainly from pyrogenic origin and petroleum sources. Oyo-Ita et al., 2013 reported a total concentration of $1,670.0$ to $20,100.0 \mathrm{ng} / \mathrm{g}$ and a mean value of $9,370 \mathrm{ng} / \mathrm{g}$ from river Calabar, Nigeria. Most PAHs have been reported to affect aquatic organisms and the ecosystem (Munyengabe et al., 2017; Zhao et al., 2017; Agneiska et al., 2017; Yang et al., 2014).

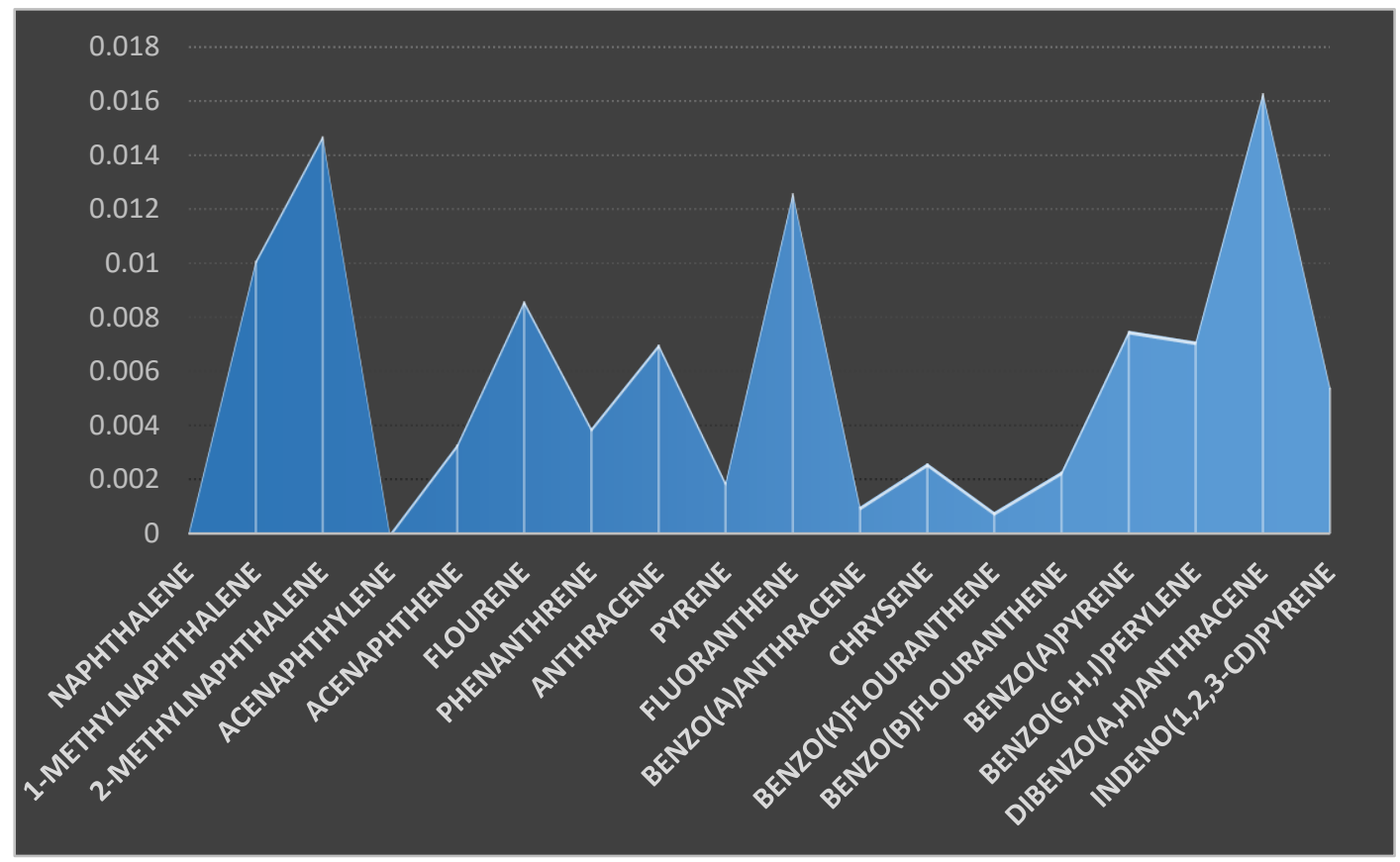

Figure 4. Concentration of PAHs components $(\mu \mathrm{g} / \mathrm{kg})$ in sediment sample from location 1.

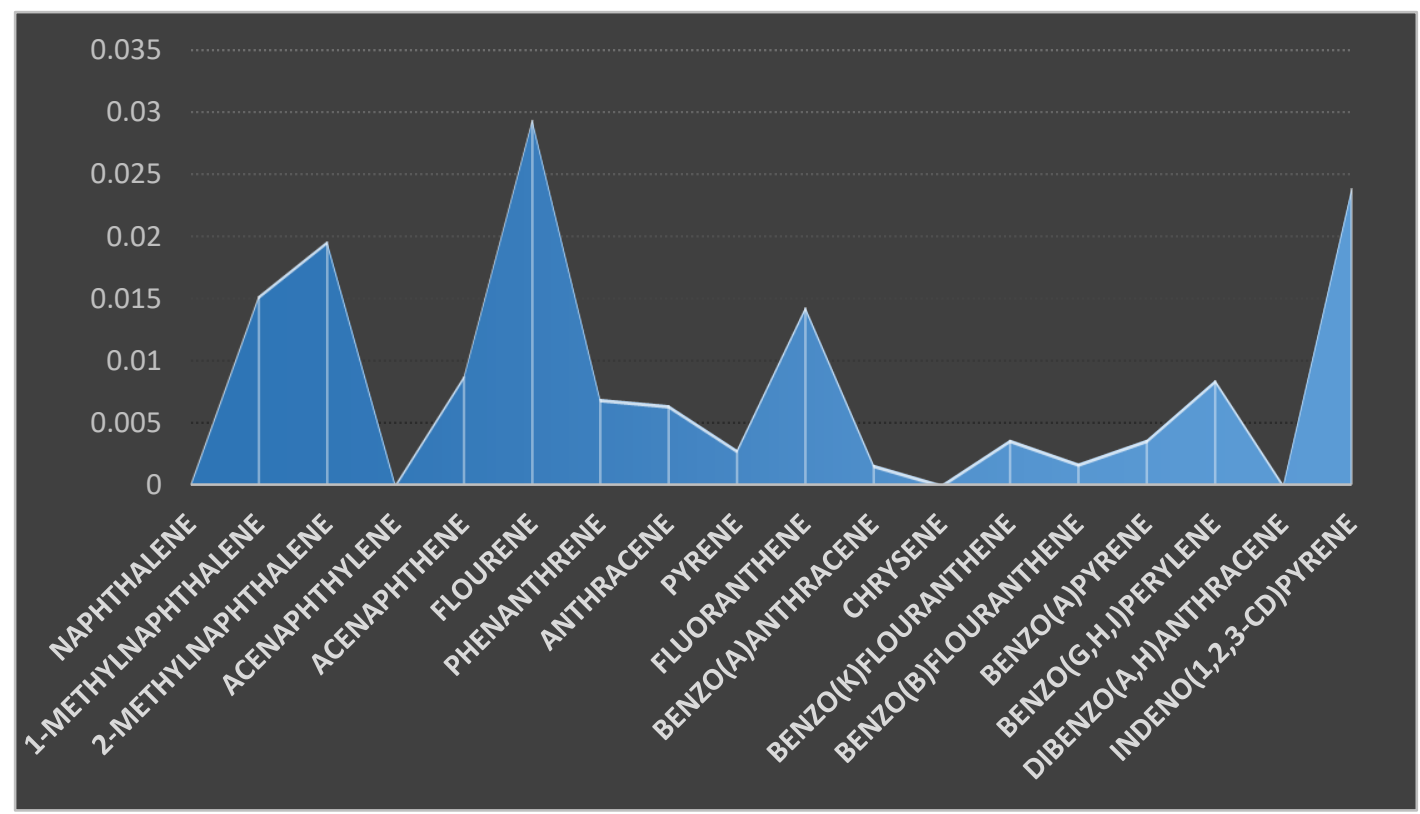

Figure 5. Concentration of PAHs components $(\mu \mathrm{g} / \mathrm{kg})$ in sediment sample from location 2.

\subsection{Concentration of PAHs in the fish sample}

The popular name of the fish is cat fish (Clarias anguillaris). It was analysed for the 18 PAHs components presented in the chart (figure 6). Four (4) PAHs components were below detection limit, 
they are: acenaphthylene, fluoranthene, benzo(a)anthracene and chrysene. The concentration of naphthalene, 1-MethylNaphthalene and 2-MethylNaphthalene were 0.0529, 0.0746 and $0.0574 \mu \mathrm{g} / \mathrm{kg}$ respectively for the fish sample. The respective concentration of acenaphthene, fluorene, phenanthrene, anthracene and pyrene were 0.0272, 0.0210, 0.0087, 0.0062 and $0.0024 \mu \mathrm{g} / \mathrm{kg}$. The concentration of benzo(k)fluoranthrene, benzo(b)fluoranthrene, benzo(a)pyrene, benzo(g,h,i)perylene, dibenzo(a,h)anthracene and indeno(1,2,3-cd)pyrene were 0.0032, 0.0009, $0.0070,0.0003,0.0001$ and $0.0385 \mu \mathrm{g} / \mathrm{kg}$. The total sum of the PAHs in the fish sample was $0.300 \mu \mathrm{g} / \mathrm{kg}$. Comparing the result of this study with a research study conducted by Asagbra, et al., (2015) to determine the concentration of PAHs in fish samples from Warri River at Ubeji, Niger Delta, Nigeria recorded a total concentration between 0-1098.5ng/g from the fish sample. Tongo et al., (2018) investigated the concentration of polycyclic aromatic hydrocarbons (PAHs) in Mullet fish (Mugil cephalus) samples from fishing areas in Amariaria Community, downstream of Bonny River, Southern Nigeria. The levels of total PAHs ranged from 0.059 to $0.126(\mu \mathrm{g} / \mathrm{kg})$.

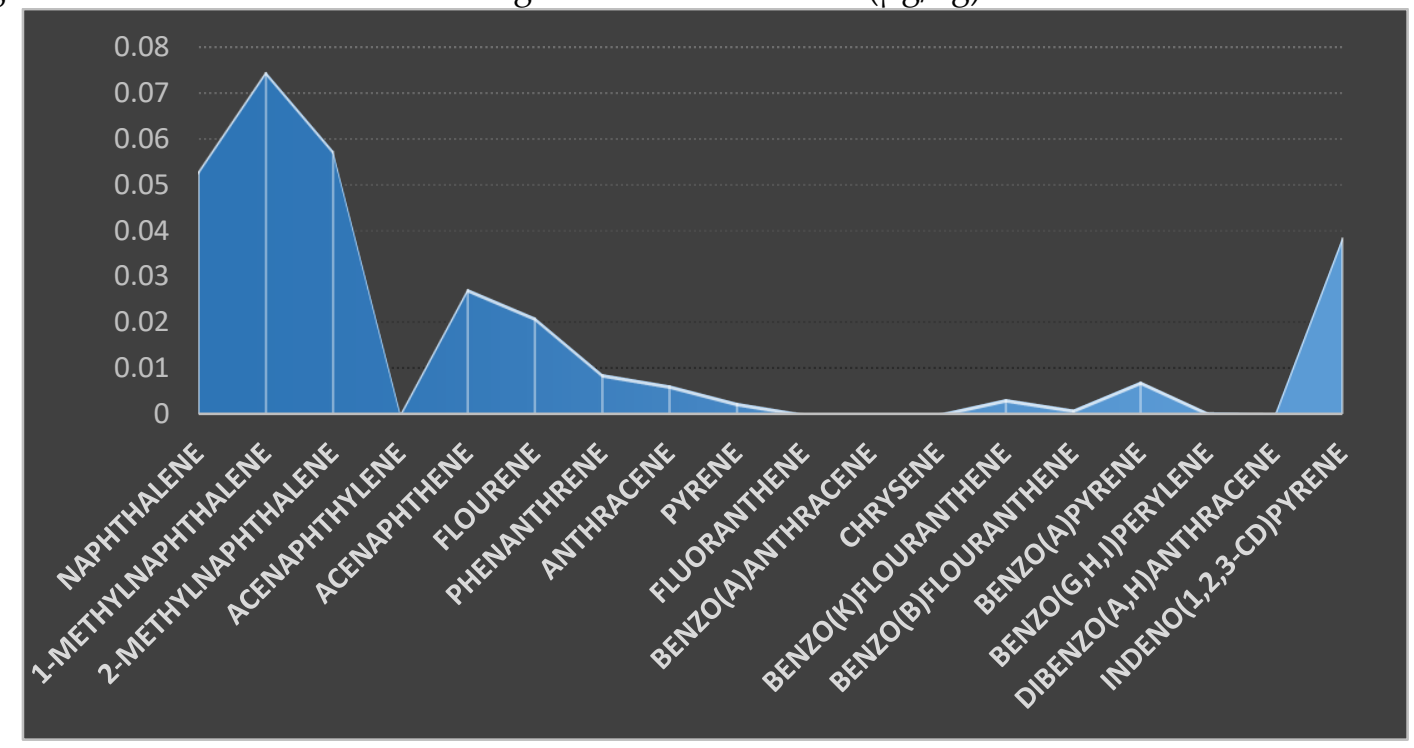

Figure 6. Concentration of PAHs components $(\mu \mathrm{g} / \mathrm{kg})$ in fish sample.

From the result presented, naphthalene and acenaphthalene were below detection limit presented in the soil and sediment samples. Naphthalene was detected in the fish sample, while acenaphthylene was below detection limit in the soil, sediment and fish samples. The total concentration of the PAHs components in the fish sample was the highest $\left(\sum 0.300 \mu \mathrm{g} / \mathrm{kg}\right)$ compared to the two soil samples $\left(\sum 0.239 \mu \mathrm{g} / \mathrm{kg}\right.$ and $\left.0.270 \mu \mathrm{g} / \mathrm{kg}\right)$ and the two sediment samples $\left(\sum 0.105 \mu \mathrm{g} / \mathrm{kg}\right.$ and $\sum 0.146 \mu \mathrm{g} / \mathrm{kg}$ ). This might be due to the bioaccumulation and bio-magnification of these PAHs components (environmental pollutants) in the fish sample. According to several researchers, fish bio accumulates and biomagnifies environmental pollutants in various organs such as skin, tissues (Fair, et al., 2018; Sun et al., 2016; Adeniyi et al., 2008).

The concentration of PAHs in the sediment samples was lower than the soil samples. Some PAHs components such as Fluoranthrene, Benzo(a)anthracene and Chrysene were below limit of detection in the fish sample but were detected in the soil and sediment samples, possibly the fish does not tend to accumulate these PAHs components.

\subsection{Contributions of the PAHs components in soil, sediment and fish samples}

Figure 7 shows the concentrations of the PAHs in all the samples, while figures 8 and 9 provide the percentage contributions of the PAHs components in soil and sediment samples while figure 10 gives the percentage composition of polycyclic aromatic hydrocarbon components in the fish sample. Flouranthrene $(18 \%)$ has the highest percentage contribution in the soil samples, followed by flourene with $13 \%$ and the least were naphthalene, acenaphthalene and others with $0 \%$. In the sediment samples, the PAHs component with the highest was contribution was flourene (15\%), followed by 2 - 
Methynaphthalene (14\%) while the least was naphthalene ( $0 \%)$. The highest \% composition from the fish sample was 1-Methylnaphthalene (25\%), 2-Methylnaphthalene was 19\% and the least was $0 \%$ for acenaphthylene and others.

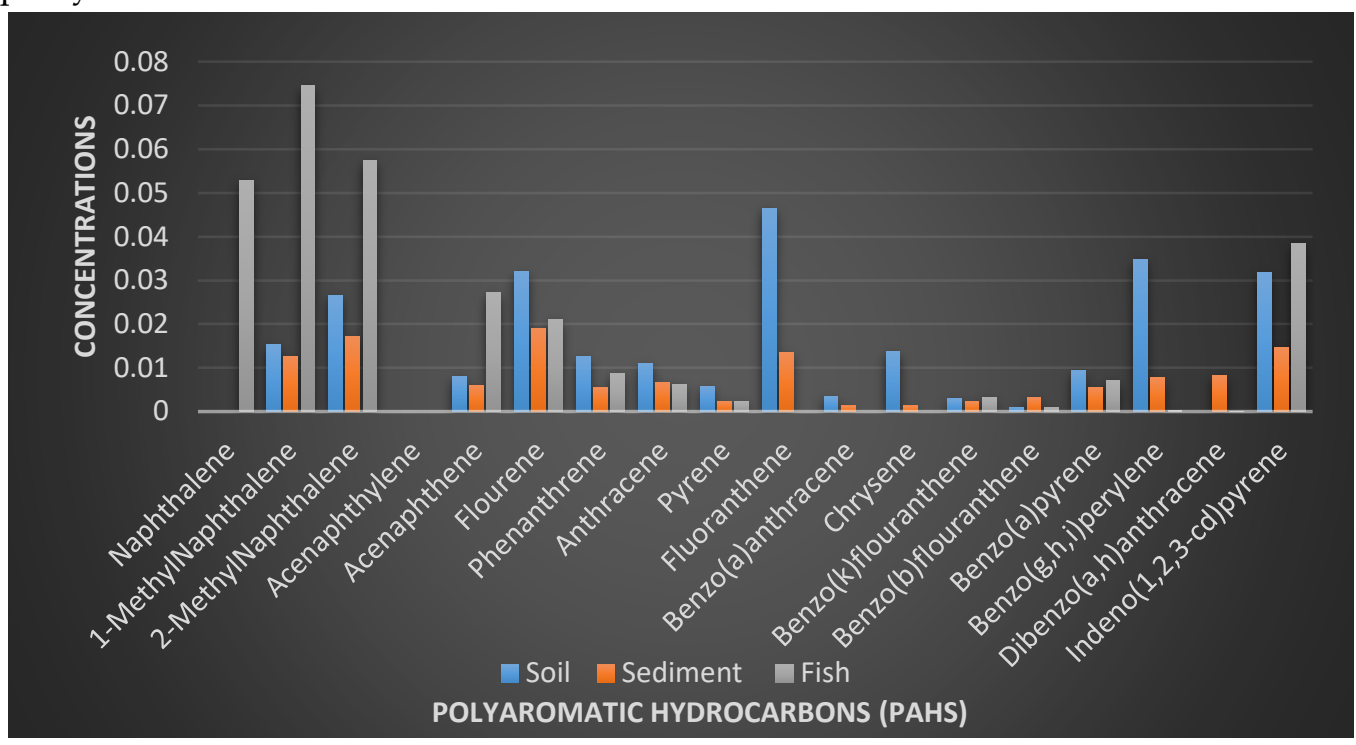

Figure 7. Concentrations $(\mu \mathrm{g} / \mathrm{kg})$ of the Polycyclic aromatic hydrocarbons (PAHs) in the samples.

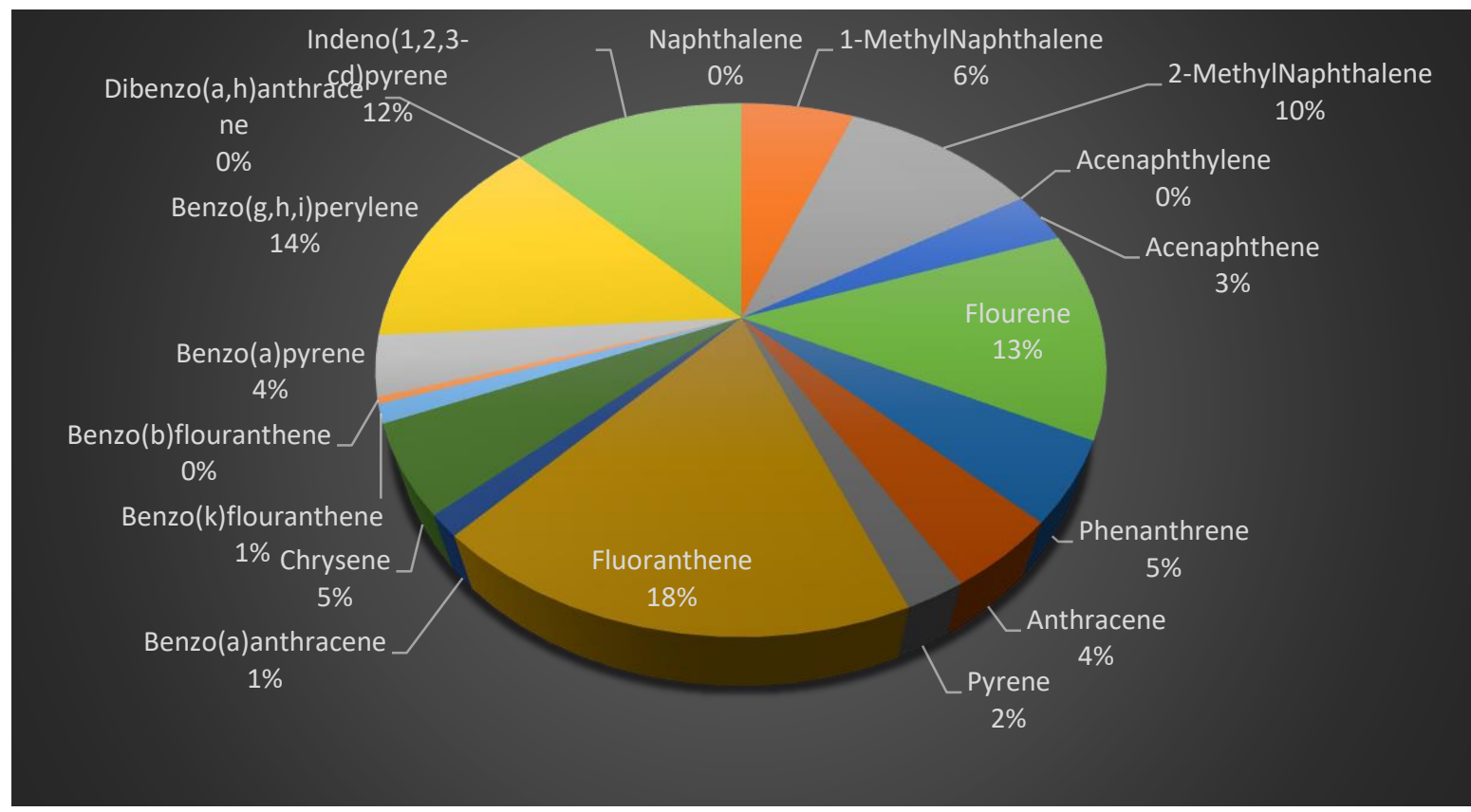

Figure 8. Percentage contributions of PAHs in the soil samples. 


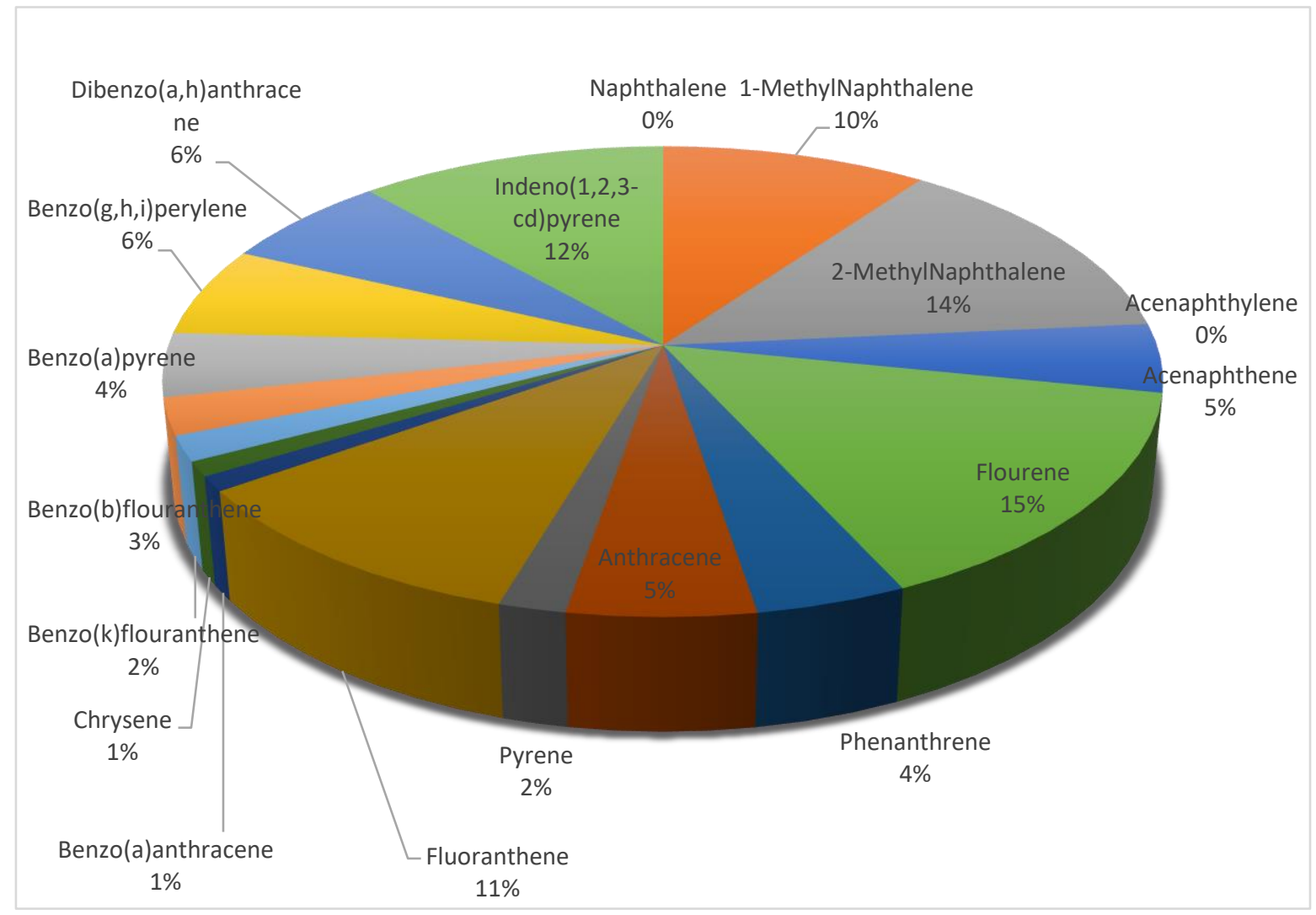

Figure 9. Percentage contributions of PAHs in the sediment samples.

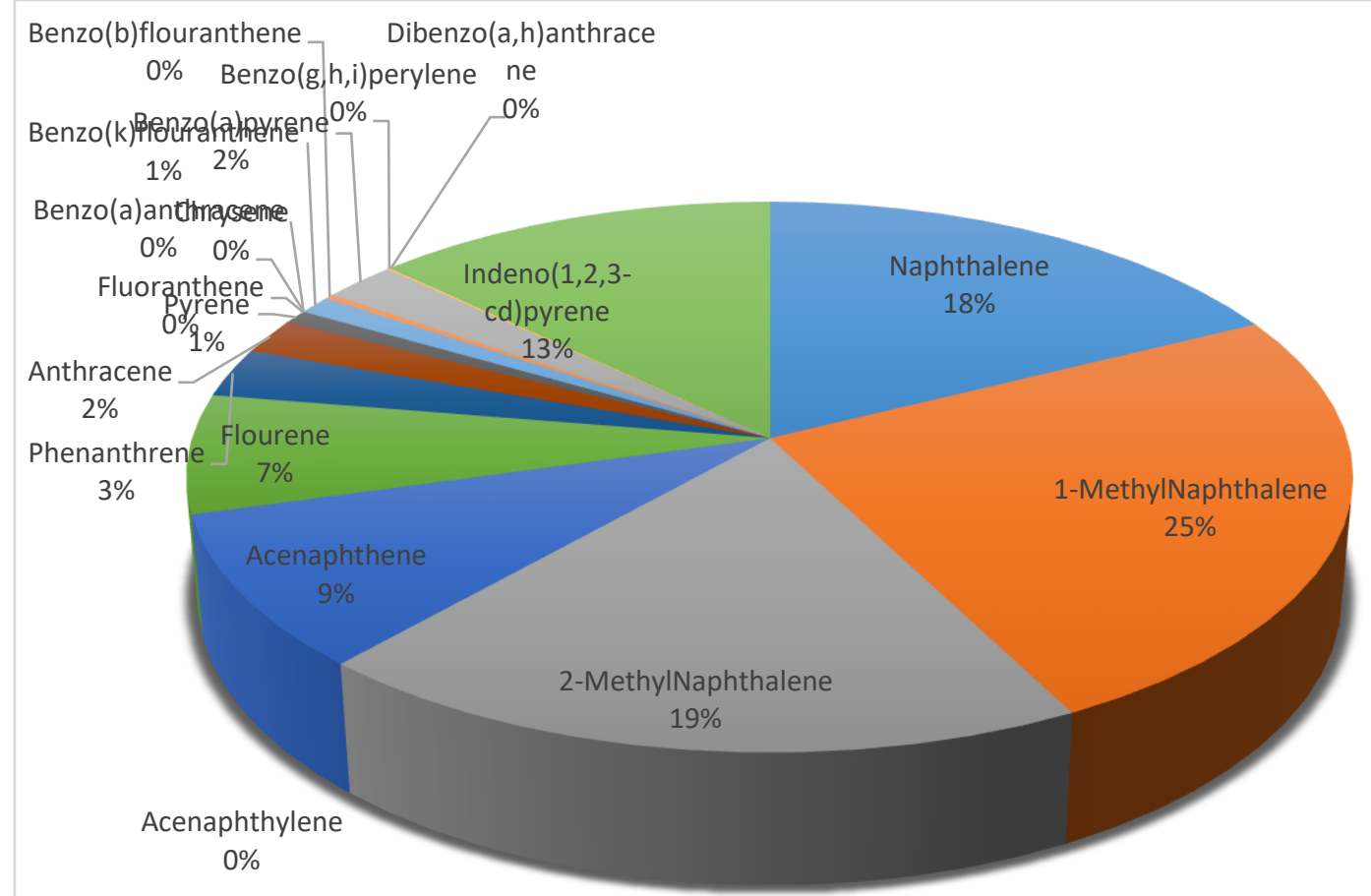

Figure 10. Percentage concentrations of the PAHs in the fish sample. 


\section{Conclusions}

The study revealed the presence of PAHs in the soil, sediment and fish samples in varying concentrations. Some PAHs components detected in the soil samples were below detection limit in the sediment samples and the fish sample. Naphthalene was detected in the fish sample but was below detection limit in the soil and sediment samples while some components detected in the soil and sediment samples were below detection limit in the fish sample. The summation of the total PAHs components in the fish sample was the highest, meaning that it accumulates the PAHs. The concentrations of PAHs in the soil samples were higher than the sediment samples.

It is going to be of necessity to further carry out research by increasing the sampling stations to cut across the communities around the river which will give room for the application of more environmental assessments such as risk assessment, pollution index, and source identification to further discuss health and ecological implications.

Acknowledgments: The authors acknowledged A. A. Ibitoye of the Federal University of Technology, Julius Okojie Central Research Laboratory, Akure (FUTA), Nigeria for his technical assistance.

\section{Appendix A}

Table A1. result of Polycyclic Aromatic Hydrocarbons (PAHs) of soil, sediment and fish samples.

\begin{tabular}{|c|c|c|c|c|c|c|}
\hline $\mathbf{S} / \mathbf{N}$ & Components & SO1 $(\mu g / k g)$ & SO2 $(\mu \mathrm{g} / \mathrm{kg})$ & SE1 $(\mu \mathrm{g} / \mathrm{kg})$ & SE2 $(\mu \mathrm{g} / \mathrm{kg})$ & F1 $(\mu \mathrm{g} / \mathrm{kg})$ \\
\hline 1. & Naphthalene & 0.0000 & 0.0000 & 0.0000 & 0.0000 & 0.0529 \\
\hline 2. & 1-MethylNaphthalene & 0.0307 & 0.0000 & 0.0101 & 0.0152 & 0.0746 \\
\hline 3. & 2-MethylNaphthalene & 0.0282 & 0.0250 & 0.0147 & 0.0196 & 0.0574 \\
\hline 4. & Acenaphthylene & 0.0000 & 0.0000 & 0.0000 & 0.0000 & 0.0000 \\
\hline 5. & Acenaphthene & 0.0065 & 0.0095 & 0.0033 & 0.0087 & 0.0272 \\
\hline 6. & Flourene & 0.0136 & 0.0506 & 0.0086 & 0.0294 & 0.0210 \\
\hline 7. & Phenanthrene & 0.0094 & 0.0155 & 0.0039 & 0.0069 & 0.0087 \\
\hline 8. & Anthracene & 0.0098 & 0.0123 & 0.0070 & 0.0064 & 0.0062 \\
\hline 9. & Pyrene & 0.0048 & 0.0067 & 0.0019 & 0.0028 & 0.0024 \\
\hline 10. & Fluoranthene & 0.0440 & 0.0490 & 0.0126 & 0.0143 & 0.0000 \\
\hline 11. & Benzo(a)anthracene & 0.0027 & 0.0041 & 0.0010 & 0.0016 & 0.0000 \\
\hline 12. & Chrysene & 0.0083 & 0.0193 & 0.0026 & 0.0000 & 0.0000 \\
\hline 13. & Benzo(k)flouranthene & 0.0003 & 0.0055 & 0.0008 & 0.0036 & 0.0032 \\
\hline 14. & Benzo(b)flouranthene & 0.0014 & 0.0006 & 0.0023 & 0.0017 & 0.0009 \\
\hline 15. & Benzo(a)pyrene & 0.0102 & 0.0084 & 0.0075 & 0.0036 & 0.0070 \\
\hline 16. & Benzo(g,h,i)perylene & 0.0463 & 0.0230 & 0.0071 & 0.0084 & 0.0003 \\
\hline 17. & Dibenzo(a,h)anthracene & 0.0000 & 0.0000 & 0.0163 & 0.0000 & 0.0001 \\
\hline 18. & Indeno(1,2,3-cd)pyrene & 0.0227 & 0.0406 & 0.0054 & 0.0239 & 0.0385 \\
\hline & Total $(\mu \mathrm{g} / \mathrm{kg})$ & 0.239 & 0.270 & 0.105 & 0.146 & 0.300 \\
\hline
\end{tabular}

SO1 - Soil sample 1, SO2 - Soil sample 2, SE1 - Sediment sample 1, SE2 - Sediment sample 2, F1 - Fish sample.

\section{References}

1. Adeniyi A. A., Yusu K. A. and Okedeji O. O. (2008). Assessment of the exposure of two fishes to metal pollution in Ogun river catchments, Ketu, Lagos, Nigeria.Journal of Environmental Assessment Monitoring 137: $451-458$.

2. Adeyemi, S. O., Bankole, N. O., Adikwu, I. A., and Akombu, P. M. (2009). Food and feeding habits of some commercially important fish species in Gbedikere Lake, Bassa, Kogi State, Nigeria. International Journal of Lakes and Rivers 2: 31-36.

3. Agnieszka, B., Marek, T., Krzysztof, U., Agnieszka, K. and Iwona, S. (2017). Concentration, sources and risk assessment of PAHs in bottom sediments, Environ. Sci. Pollut. Res. 24:23180-23195.

4. Asagbra, M. C., Adebayo, A. S., Anumudu, C. I., Ugwumba, O. A. and Ugwumba, A. A. A. (2015). Polycyclic aromatic hydrocarbons in water, sediment and fish from the Warri River at Ubeji, Niger Delta, Nigeria. African Journal of Aquatic Science: 1-7.

5. Banger, K., Toor, G. S., Chirenje, T., and Ma, L. (2010). Polycyclic aromatic hydrocarbons in urban soils of different land uses in Miami, Florida. Soil and Sediment Contamination, 19(2), 231-243.1. 
6. Botkin, B. and Keller, E. (2014). Environmental Science-Earth as a Living Planet. 9th edition. U.S.A.: Wiley.

7. Cui, X. Y., Xiang, P., He, R. W., Juhasz, A., and Ma, L. Q. (2016). Advances in in vitro methods to evaluate oral bioaccessibility of PAHs and PBDEs in environmental matrices. Chemosphere, 150, 378-389.

8. Fair, P. A., White, N. D., Wolf, B., Arnott, S. A. Kannan, K., Karthikraj, R. and Vena, J.E. (2018). Persistent organic pollutants in fish from Charleston Harbor and tributaries, South Carolina, United States: A risk assessment. Environmental Research, Vol. 167, Pages 598-613.

9. Feng, C., Luo, Q., and Wang, Z. (2009). Concentration levels and potential ecological risks of polycyclic aromatic hydrocarbons in Chinese rivers. Water Quality, Exposure and Health, 1(2), 105-113.

10. Gan, S., Lau, E. V., and Ng, H. K. (2009). Remediation of soils contaminated with polycyclic aromatic hydrocarbons (PAHs). Journal of Hazardous Materials, 172(2-3), 532-549.

11. Gao, P., da Silva, E., Hou, L., Denslow, N. D., Xiang, P., and Ma, L. Q. (2018). Human exposure to polycyclic aromatic hydrocarbons: Metabolomics perspective. Environment International, 119, 466-477.

12. Hussein I. Abdel-Shafy and Mona S.M. Mansour. (2016). A review on polycyclic aromatic hydrocarbons: Source, environmental impact, effect on human health and remediation. Egyptian Journal of Petroleum, Vol. 25, 107-123.

13. Jiao, H.H., Rui, X.P., Wu, S.H., Bai, Z.H., Zhuang, X.L. and Huang, Z.B. (2015). Polycyclic aromatic hydrocarbons in the Dagang Oilfield (China): Distribution, sources, and risk assessment. Int. J. Environ. Res. Public Health, 12, 5775-5791.

14. Kim, L., Jeon, H., Kim, Y., Yang, S., Choi, H. and Kim, T and Lee, S. (2019). Monitoring polycyclic aromatic hydrocarbon concentrations and distributions in rice paddy soils from Gyeonggi-do, Ulsan, and Pohang. Appl. Biol. Chem. 62:18.

15. Kuppusamy, S., Thavamani, P., Venkateswarlu, K., Lee, Y. B., Naidu, R., and Megharaj, M. (2016). Remediation approaches for polycyclic aromatic hydrocarbons (PAHs) contaminated soils: Technological constraints, emerging trends and future directions. Chemosphere, 168, 944-968.

16. Lang, Y. H., Li, G. L., Wang, X. M., and Peng, P. (2015). Combination of Unmix and PMF receptor model to apportion the potential sources and contributions of PAHs in wetland soils from Jiaozhou Bay, China. Marine Pollution Bulletin, 90(1-2), 129-134.

17. Lasheen, M. R., Abdel-Gawad, F. K., Alaneny, A. A., and Abd El Bary, H. M. (2012). Fish as bioindicators in aquatic environmental pollution assessment: a case study in Abu-Rawasharea, Egypt. World Applied Sciences Journal 19: 265-275.

18. Lau, E. V., Gan, S., and Ng, H. K. (2010). Extraction techniques for polycyclic aromatic hydrocarbons in soils. International Journal of Analytical Chemistry, 2010, 398381.

19. Li, C., Cui, X. Y., Fan, Y. Y., Teng, Y., Nan, Z. R. and Ma, L. Q. (2015). Tenax as sorption sink for in vitro bio-accessibility measurement of polycyclic aromatic hydrocarbons in soils. Environmental Pollution, 196, $47-52$.

20. Li, Q.,Wang, N.,Wu, X., Pu, J., He, J. and Zhang, C. (2011). Sources and distribution of polycyclic aromatic hydrocarbons of different glaciers over the Tibetan Plateau. Sci. China Earth, Sci. 54, 1189-1198.

21. Mirza. R., Mohammadi, M., Faghiri, I., Abedi, E., Ali. F., Ali, A. and Mohammad, A. Z. (2014). Source identification of polycyclic aromatic hydrocarbons (PAHs) in sediment samples from the northern part of the Persian Gulf, Iran. Environ Monit. Assess. 186:7387-7398.

22. Mahmoud, A. A. and Abbas, L. A. (2016). Study of polycyclic aromatic hydrocarbons (PAHs) in soil samples from Al-Ahdab oil field in Waset Region, Iraq, Toxin Reviews, 35:3-4, 69-76.

23. Munyengabe A, Mambanda A, and Moodley, B. (2017). Polycyclic Aromatic Hydrocarbons in Water, Soils and Surface Sediments of the Msunduzi River. J. Environ. Anal. Chem. 4: 227.

24. Muntean, N., Muntean, E. and Duda, M. M. (2015). Polycyclic Aromatic Hydrocarbons in Soil. Proenvironment, 8: 285 - 289.

25. Lawal, T. A. (2017). Polycyclic aromatic hydrocarbons. A review, Cogent Environmental Science, $3: 1339841$.

26. Ogunfowokan, A.O., Asubiojo, O.I. and Fatoki, O.S. (2003). Isolation and determination of polycyclic aromatic hydrocarbons in surface runoff and sediments. Water Air Soil Pollut., 147, 245-261.

27. Okedeyi, O.O., Nindi, M. M., Dube, S. and Awofolu, O.R. (2013). Distribution and potential sources of polycyclic aromatic hydrocarbons in soils around coal-fired power plants in South Africa. Environ. Monit. Assess., 185, 2073-2082.

28. Orecchio, S., and Papuzza, V. (2009). Levels, fingerprint and daily intake of polycyclic aromatic hydrocarbons (PAHs) in bread baked using wood as fuel. Journal of Hazardous Materials, 164(2-3), 876-883. 
29. Oyakhilome, G. I., Ajiwe, V. I. E. and Akinola, O. K. (2019). The Microbial Status and Physico-Chemical Pollutants Studies of Rivers Owan and Evbiobe in Edo State, Nigeria. Science Journal of Analytical Chemistry, Vol. 7, No. 2, (57-64).

30. Oyo-Ita, O. E., Offem, J. O., Ekpo, B. O. and Adie, P. A. (2013). Anthropogenic PAHs in mangrove sediments of the Calabar River, SE Niger Delta, Nigeria. Applied Geochemistry, Vol. 28, Pages 212-219.

31. Srogi, K. (2007). Monitoring of environmental exposure to polycyclic aromatic hydrocarbons: A review. Environmental Chemistry Letters, 5(4), 169-195.

32. Sun, C., Zhang, J., Ma, Q. and Chen, Y. (2015). Human Health and Ecological Risk Assessment of 16 Polycyclic Aromatic Hydrocarbons in Drinking Source Water from a Large Mixed-Use Reservoir. Int. J. Environ. Res. Public Health, 12, 13956-13969.

33. Sun, C., Zhang, J., Ma, Q., Zhang, F. and Chen, Y. (2016). Risk assessment of polycyclic aromatic hydrocarbons (PAHs) in sediments from a mixed-use reservoir, Human and Ecological Risk Assessment: An International Journal, 22:2, 447-459.

34. Tongo, I., Etor, E. E. and Ezemonye, L. (2018). Human Health Risk Assessment of PAHs in Fish and Shellfish from Amariaria Community, Bonny River, Nigeria. J. Appl. Sci. Environ. Manage. Vol. 22 (5) 731736.

35. Upadhi, F., and Wokoma, O. A. F. (2012). Examination of some pesticide residues in surface water, sediment and fish tissue of Elechi Creek, Niger Delta. Nigeria, Research Journal of Environmental and Earth Sciences, 4(11), 939-944.

36. US Environmental Protection Agency (USEPA) (1986). Analysis of Polynuclear aromatic hydrocarbons. Method 8100. US Environmental Protection Agency.

37. Wang, X. T., Miao, Y., Zhang, Y., Li, Y. C., Wu, M. H., and Yu, G. (2013). Polycyclic aromatic hydrocarbons (PAHs) in urban soils of the megacity Shanghai: Occurrence, source apportionment and potential human health risk. Science of the Total Environment, 447, 80-89.

38. Yang, Y., Lee Ann Woodward, L. A., Li, Q. X. and Wang, J. (2014). Concentrations, Source and Risk Assessment of Polycyclic Aromatic Hydrocarbons in Soils from Midway Atoll, North Pacific Ocean. PLoS ONE 9(1): e86441.

39. Yu, W., Liu, R., Wang, J., Xu, F., and Shen, Z. (2015). Source apportionment of PAHs in surface sediments using positive matrix factorization combined with GIS for the estuarine area of the Yangtze River, China. Chemosphere, 134, 263-271.

40. Zheng, H., Kang, S., Chen, P., Li, Q., Tripathee, L., Maharjan, L., Guo, J., Zhang, Q. and Santos, E. (2020). Sources and spatio-temporal distribution of aerosol polycyclic aromatic hydrocarbons throughout the Tibetan Plateau. Environmental Pollution, 261: 114144.

41. Zhao, Z., Qin, Z., Cao, J. and Xia, L. (2017). Source and Ecological Risk Characteristics of PAHs in Sediments from Qinhuai River and Xuanwu Lake, Nanjing, China. Journal of Chemistry, Volume 2017.

42. Zhao, Z.; Zhuang, Y.; Gu, J. (2012). Abundance, composition and vertical distribution of polycyclic aromatic hydrocarbons in sediments of the Mai Po Inner Deep Bay of Hong Kong. Ecotoxicology, 21, 1734-1742. 